\title{
A Catalytic, Oxidative Synthesis of Olivetol, Methyl Olivetolate and Orthogonally Protected Methyl Ether Derivatives
}

\author{
David Hurem ${ }^{a}$ \\ Benjamin J. Macphailb \\ Rina Carlinib \\ Jason Lewis \\ James McNulty*a (i) \\ a Department of Chemistry \& Chemical Biology, McMaster University, \\ 1280 Main Street West, Hamilton, Ontario, L8S 4M1, Canada \\ jmcnult@mcmaster.ca \\ b Rapid Dose Therapeutics, 1121 Walkers Line, Suite 3, Burlington, \\ Ontario, L7N 2G4, Canada
}

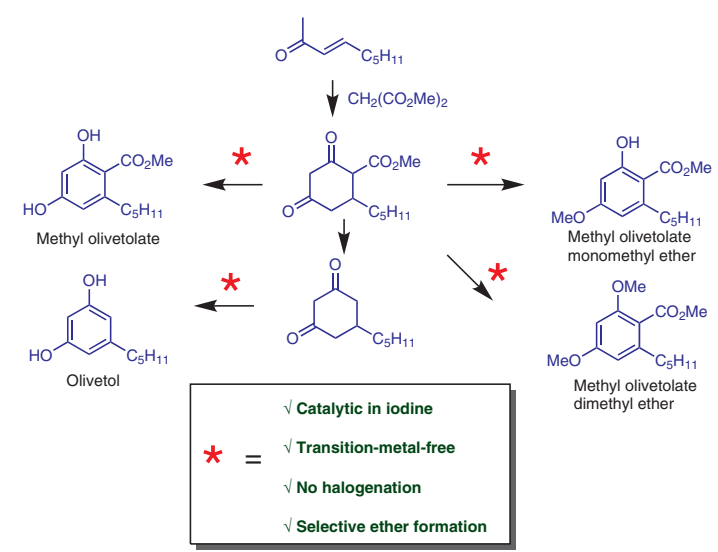

Received: 23.02.2021

Accepted after revision: 15.03 .2021

Published online: 16.03 .2021

DOI: 10.1055/a-1440-9732; Art ID: so-2021-d0011-I

License terms: cc)

(c) 2021. The Author(s). This is an open access article published by Thieme under the terms of the Creative Commons Attribution-NonDerivative-NonCommercial-License, permitting copying and reproduction so long as the original work is given appropriate credit. Contents may not be used for commercial purposes or adapted, remixed, transformed or built upon. (https://creativecommons.org/licenses/by-nc-nd/4.0/)

Abstract Olivetol, methyl olivetolate and a series of orthogonally protected methyl ether derivatives were synthesized from commonly available precursors using an atom-economical, catalytic oxidative aromatization process.

Key words olivetol, olivetolic acid, aromatization, catalysis, oxidation, polyketide, meroterpenoid

Resorcylates such as orcinol (3,5-dihydroxytoluene) and olivetol 1 (Scheme 1) form the central core of many condensed polyketide aromatic natural products and higher analogues. These include methylated derivatives and dimers such as griseofulvin, usnic acid and alternariol, as well as the large class of prenylated meroterpenoid natural products. Of notable significance among the latter class are the phytocannabinoids isolated from Cannabis sativa. Over 100 such phytocannabinoids, including (-)-trans- $\Delta^{9}$-tetrahydrocannabinol 6 (THC) and (-)-cannabidiol 7 (CBD) have been identified ${ }^{1 \mathrm{~d}}$ among almost 600 natural products that have been profiled in cannabis extracts. ${ }^{1 \mathrm{e}}$ While much attention has focused on the pharmacological properties of THC $6,{ }^{1 \mathrm{f}} \mathrm{CBD} 7^{1 \mathrm{~g}}$ and cannabinol, ${ }^{1 \mathrm{~h}}$ a wide range of biological activities continue to be reported for these and the lesser known cannabinoids. ${ }^{1,2}$ The natural products are biosynthesized through geranylation of 5-alkyl resorcinol carboxylic acid derivatives such as orsellinic acid and olivetolic acid 2. Olivetolic acid is thus a central intermediate in the biosynthesis of the phytocannabinoids, while olivetolic acid and more commonly olivetol are crucial building blocks in the chemical synthesis of phytocannabinoids and analogues. Efforts in the chemical synthesis of these phytocannabinoids and similar meroterpenes have therefore historically and continue to involve the regioselective terpenylation of olivetol $1 .^{3}$

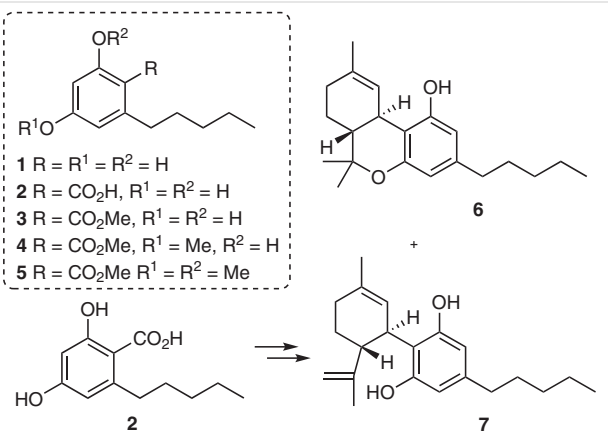

Scheme 1 Polyketide precursors in the chemical and biological synthesis of phytocannabinoids

We became interested in the synthesis of 5-alkylresorcinols such as olivetol and olivetolic ester derivatives for several reasons. Recently, olivetol and olivetolic acid derivatives have been shown to modulate (selective agonists or antagonists) the pharmacology of human cannabinoid $\mathrm{CB}_{1}$ and $\mathrm{CB}_{2}$ receptors, ${ }^{4 \mathrm{a}, \mathrm{b}}$ and cannabidiolic acid analogues have been shown to exhibit anticonvulsant activity in a mouse model of Dravet syndrome. ${ }^{4 c}$ It has also been shown that variations in the length and branching of the C5-substituent on the olivetol fragment can have significant effects on the potency of the derived cannabinoids. ${ }^{1 \mathrm{~d}, 4 \mathrm{~d}-\mathrm{f}}$ Terpenylation of 
C5-variable olivetol derivatives ${ }^{4 \mathrm{~d}-\mathrm{f}}$ is the most direct synthetic route to these analogues. The regioselective terpenylation of olivetolic acid ester derivatives has been shown to proceed with very high regioselectivity in favour of the natural meroterpenoid cores..$^{5 e, f}$ The various synthetic efforts towards olivetol $\mathbf{1}^{5}$ require the use of stoichiometric oxidants, such as elemental bromine, under harsh conditions that do not permit access to olivetolate esters, which are otherwise not commercially available. In this communication, we report a short synthesis of olivetol $\mathbf{1}$ through a mild, atom-economical oxidative process that is catalytic in iodine, as well as methyl olivetolate $\mathbf{3}$ and the orthogonally methylated ether analogues $\mathbf{4}$ and $\mathbf{5}$.

The most efficient synthesis of olivetol $\mathbf{1}$ to date involves preparation of the cyclic diketo ester $\mathbf{8}$ and subsequent saponification/decarboxylation to diketone 9. Intermediate $\mathbf{8}$ (or less efficiently $\mathbf{9}$ ) is then converted into oliveteol through thermolysis in DMF using a stoichiometric amount of bromine (Scheme 2). ${ }^{5 a}$ The oxidation process required forcing conditions which must be controlled carefully to limit the formation of over-brominated aromatic byproducts. ${ }^{5 \mathrm{~b}}$ Although other routes have been reported, they generally suffer from either high cost of starting materials, such as 3,5-dimethoxybenzene or 3,5-dimethoxybenzoic acid, or employ techniques that are operationally prohibitive at scale..$^{\text {b-f }}$ Olivetolic acid or ester derivatives such as $\mathbf{3}$ are not directly obtained in this method but may be subsequently accessed from olivetol $\mathbf{1}$ via ortho-lithiation and carbonylation of its corresponding dimethyl ether derivative, ${ }^{5 \mathrm{~h}}$ or via other more complex routes..$^{5 \mathrm{e}}$

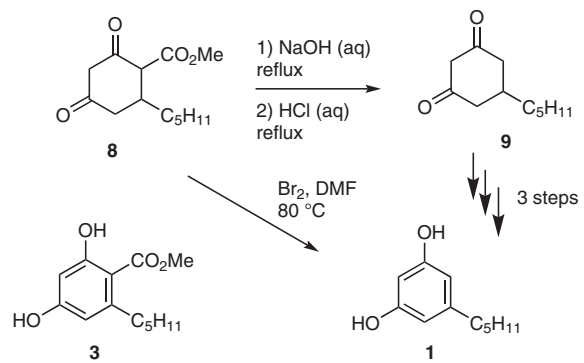

Scheme 2 Previous routes to olivetol and olivetolic acid methyl ester

Oxidative aromatization (dehydrogenation) of cyclohexanones as a method for synthesis of arenes, including phenols, has been investigated for decades, and has received recent renewed interest (Scheme 3). ${ }^{6}$

Catalytic dehydrogenation of cyclic enones using palladium on carbon was reported to afford phenols with varying degrees of success (Scheme $3, \mathrm{i}) .^{7}$ However, the use of transition-metal catalysts in the late stage of olivetol synthesis was considered not ideal for the purpose of this synthetic effort due to issues of cost (Pd) and possible transition-metal contamination in the products. The oxidative aromatization of enones to give the corresponding phenols

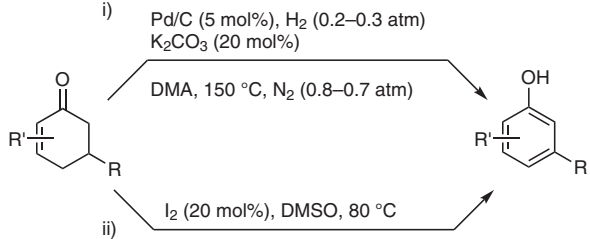

Scheme 3 Methods for catalytic oxidative aromatization

using catalytic iodine in DMSO as the terminal has more recently been reported (Scheme 3 , ii), but not applied to olivetol or derivatives. ${ }^{8}$ Earlier reports described the use of excess iodine (2.00 equivalents) to give a 5-methyl resorcinol monomethyl ether ${ }^{9 a, b}$ from a cyclic diketone similar to 9. We hypothesized that the redox equivalent 1,3-diketones, $\mathbf{8}$ and $\mathbf{9}$, could be oxidized using catalytic quantities of iodine in DMSO to afford olivetol and olivetolate esters. Here, we report the success of this method for selective oxidative aromatization, an improved synthesis of olivetol, high yielding synthesis of methyl olivetolate, and access to synthetically useful orthogonally protected methyl ether derivatives.

The syntheses of the cyclic diketo-ester $\mathbf{8}$ and diketone $\mathbf{9}$ were accomplished as previously outlined by Focella et al. ${ }^{5 a}$ The isolation of both intermediates was explored and it was found that both $\mathbf{8}$ and $\mathbf{9}$ could be isolated by precipitation from the corresponding reaction mixtures, and that the entire sequence can be carried through sequentially to obtain 9 in 84\% isolated yield over three steps (Scheme 4). ${ }^{10,11}$

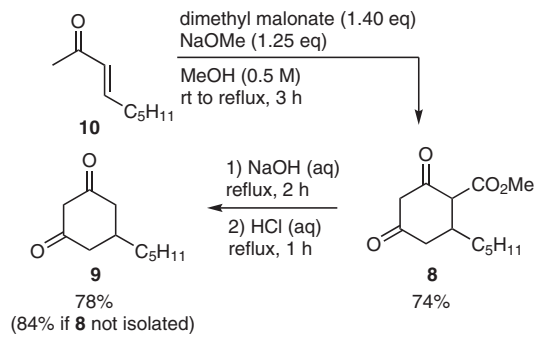

Scheme 4 Synthesis of diketone intermediates

Turning to the oxidation/aromatization process, we initially focussed on the ester derivative 8 . To our delight, oxidative aromatization was observed to proceed smoothly using a catalytic quantity (20 mol\%) of molecular iodine in dimethyl sulfoxide (DMSO) giving methyl olivetolate 3 in $88 \%$ isolated yield (Table 1, entry 1 ).

The reaction was equally successful at higher concentrations (Table 1 , entry 2 ) requiring less solvent use, and the loading of the catalytic amount of iodine could be lowered to $10 \%$ (entry 3 ) with no detriment to yield. The reaction appeared to be incredibly robust with respect to concentration and catalyst loading. The aromatic methyl ester $\mathbf{3}$ was readily isolated by solvent partition (EtOAc) from aqueous 
Table 1 Catalytic Oxidation of Ketones

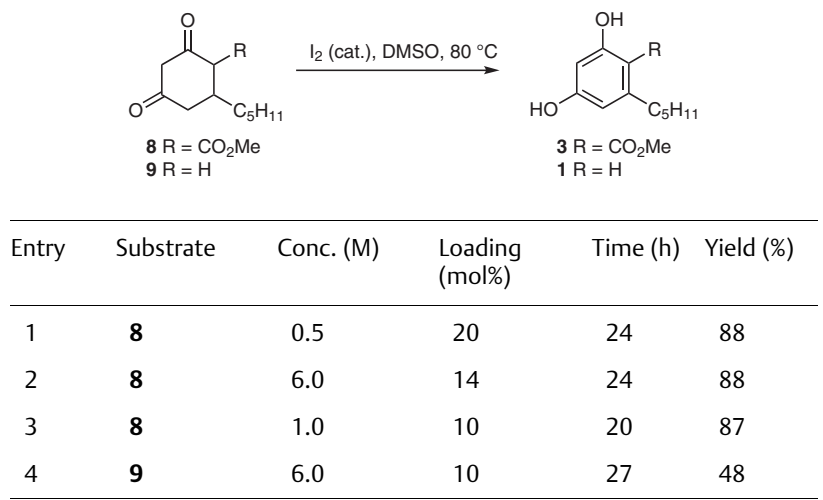

sodium thiosulfate, filtration through a short silica-gel plug and removal of solvent, yielding the desired product as a slightly yellow crystalline solid. Conditions to effect oxidation of $\mathbf{9}$ were similarly developed (entry 4 ) leading to olivetol 1. The conversion could be effected in high yield. Work-up as before and removal of solvent yielded olivetol 1 in high yield. Purification via high-vacuum distillation resulted in highly pure olivetol $\mathbf{1}$, which was isolated in $48 \%$ yield as a colourless crystalline solid.

Aromatization in the presence of methanol was next explored as a method for obtaining methylated derivatives of 3 (Scheme 5). To this end, it was found that selective methyl ether formation could be accomplished by using methanol as a solvent with a stoichiometric amount of DMSO and catalytic iodine (Scheme 5 , a). This procedure results in formation of methyl olivetolate $\mathbf{3}$ and the mono methyl ether $\mathbf{4}$, in a 70:30 ratio, readily separable using flash column chromatography resulting in the efficient isolation of $\mathbf{3}(65 \%)$ and 4 (27\%). Various modifications of these reaction conditions did not appear to have a noticeable effect on the overall ratio of products observed. We postulated that enol ether hydrolysis (vinylogous ester) may be taking place during the aromatization process. In order to limit this potential, trimethyl orthoformate (TMOF) was used (Scheme 5, b) to dramatic effect. In this case, the mono methyl ether $\mathbf{4}$ and methyl olivetolate-dimethyl ether $\mathbf{5}$ were obtained in high yield and no trace of methyl olivetolate $\mathbf{3}$ was observed. The orthogonally protected methyl olivetolates were readily separable using silica-gel flash chromatography, resulting in the efficient preparation of $\mathbf{5}$ and $\mathbf{4}$ in $49 \%$ and $21 \%$ isolated yield, respectively. This method represents a simple alternative to $O$-methylation of the resorcylates using dangerous methylating agents and permits selective access to the orthogonally protected methyl olivetolate mono- and dimethyl ethers in 100-200 mg quantities at the scale reported herein.

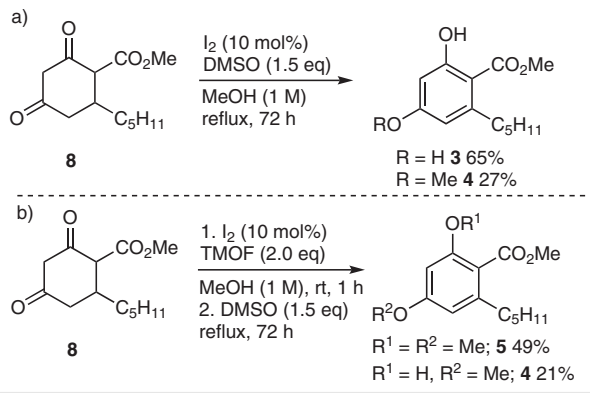

Scheme 5 Synthesis of methylated derivatives

In conclusion, the synthesis of olivetolic acid methyl ester $\mathbf{3}$ has been achieved in 65\% isolated yield in only two steps from the cyclic diketone $\mathbf{8}$ employing an oxidative aromatization strategy that is catalytic in iodine in DMSO. ${ }^{12}$ Similarly, the synthesis of olivetol 1 was achieved in $40 \%$ yield over two steps from diketone $\mathbf{9}$ using this method. ${ }^{13}$ Process methods were developed that allow isolation of both products without the use of preparative chromatography. The oxidative aromatization reaction performed in the presence of methanol and, more strikingly, trimethylorthoformate, resulted in the development of efficient routes to the mono- $\mathbf{4}$ and dimethyl $\mathbf{5}$ ethers of methyl olivetolate. ${ }^{14,15}$ These results demonstrate the success of the catalytic oxidative aromatization synthetic route to olivetol and orthogonally protected methyl olivetolate ethers. The selective oxidative aromatization proceeds with no detectable halogenation ${ }^{5 a, b}$ and the process routes developed provide the products with high mass balance. The compounds prepared here provide a valuable platform for the synthesis of other resorcylates and enable access to resorcinol and olivetol derivatives with variable length alkyl chains. The preparation of cannabinoids and analogues via regioselective terpenylation reactions employing the intermediates presented here is under active investigation in our laboratories.

\section{Conflict of Interest}

The authors declare no conflict of interest.

\section{Funding Information}

We thank the Natural Sciences and Engineering Council of Canada for financial support in the form of a Collaborative Research and Development award (CRDPJ 530888-18).

\section{Supporting Information}

Supporting information for this article is available online at https://doi.org/10.1055/a-1440-9732. Full details on the synthetic procedures and characterization data on the products are included. 


\section{References and Notes}

(1) (a) Mechoulam, R.; Mccallum, N. K.; Burstein, S. Chem. Rev. 1976, 76, 75. (b) Mechoulam, R.; Ben-Shabat, S. Nat. Prod. Rep. 1999, 16, 131. (c) Weiblen, G. D.; Wenger, J. P.; Craft, K. J.; ElSohly, M. A.; Mehmedic, Z.; Treiber, E. L.; Marks, M. D. New Phytol. 2015, 208, 1241. (d) Welling, M. T.; Liu, L.; Raymond, C. U.; Ansari, O.; King, G. J. Front. Plant Sci. 2018, 9, 1510. (e) Lewis, M. M.; Yang, Y.; Wasilewski, E.; Clarke, H. A.; Kotra, L. P. ACS Omega 2017, 2, 6091. (f) Banister, S. D.; Arnold, J. C.; Connor, M.; Glass, M.; McGregor, I. S. ACS Chem. Neurosci. 2019, 10, 2160. (g) Nelson, K. M.; Bisson, J.; Singh, G.; Graham, J. G.; Chen, S.-N.; Friesen, J. B.; Dahlin, J. L.; Niemitz, M.; Walters, M. A.; Pauli, G. F. J. Med. Chem. 2020, 63, 12137. (h) Nandaluru, P. R.; Bodwell, G. J. Org. Lett. 2012, 14, 310.

(2) (a) Grotenhermen, F.; Russo, E.; Zuardi, A. W. Cannabis Cannabinoid Res. 2017, 2, 1. (b) Hill, K. P. JAMA, J. Am. Med. Assoc. 2015, 313, 2474. (c) Rhyne, D. N.; Anderson, S. L.; Gedde, M.; Borgelt, L. M. Pharmacotherapy 2016, 36, 505. (d) Welty, T. E. W.; Luebke, A.; Gidal, B. E. Epilepsy Curr. 2014, 14, 250. (e) Porter, B. E.; Jacobson, C. Epilepsy Behav. 2013, 29, 574. (f) Bostwick, J. M. Mayo Clin. Proc. 2012, 87, 172. (g) Gutzeit, H. O.; Ludwig-Muller, J. In Plant Natural Products, Synthesis, Biological Functions and Practical Applications; Wiley-Blackwell: Weinheim, 2014, 307339. (h) Morales, P.; Reggio, P. H.; Jagerovic, N. Front. Pharmacol. 2017, 8, DOI: 10.3389/fphar.2017.00422.

(3) (a) Mechoulam, R.; Shvo, Y. Tetrahedron 1963, 19, 2073. (b) Gaoni, Y.; Mechoulam, R. J. Am. Chem. Soc. 1964, 86, 1646. (c) Mechoulam, R.; Gaoni, Y. J. Am. Chem. Soc. 1965, 87, 3274. (d) Baek, S.-H.; Srebnik, M.; Mechoulam, R. Tetrahedron Lett. 1985, 26, 1083. (e) Yeom, H. S.; Li, H.; Tang, Y. R.; Hsung, P. Org. Lett. 2013, 15, 3130. (f) Giorgi, P. D.; Liautard, V.; Pucheault, M.; Antoniotti, S. Eur. J. Org. Chem. 2018, 1307.

(4) (a) Cascio, M. G.; Bisogno, T.; Palazzo, E.; Thomas, A.; van der Stelt, M.; Brizzi, A.; de Novellis, V.; Marabese, I.; Ross, R.; van de Doelen, T.; Brizzi, V.; Pertwee, R.; Maione, S.; Di Marzo, V. Br. J. Pharmacol. 2006, 149, 431. (b) Carberry, J. J. International Patent Application WO 2017/091755 A1, 2017. (c) Anderson, L. L.; Low, I. K.; Banister, S. D.; McGregor, I. S.; Arnold, J. C. J. Nat. Prod. 2019, 82, 3047. (d) Citti, C.; Linciano, P.; Russo, F.; Luongo, L.; Iannotta, M.; Maione, S.; Lagana, A.; Caprioti, A. L.; Forni, F.; Vandelli, M. A.; Gigli, G.; Cannazza, G. Sci. Rep. 2019, 20335. (e) Linciano, P.; Citti, C.; Luongo, L.; Belardo, C.; Maione, S.; Vandelli, M. A.; Forni, F.; Gigli, G.; Lagana, A.; Montone, C. M.; Cannazza, G. J. Nat. Prod. 2020, 83, 88. (f) For a summary of developing drug candidates containing modified side chains see: Erickson, B. E. Chem. Eng. News 2020, 98, 16.

(5) (a) Focella, A.; Teitel, S.; Brossi, A. J. Org. Chem. 1977, 42, 3456. (b) Anker, K. M.; Cook, A. H. J. Chem. Soc. 1945, 311. (c) Marmor, R. S. J. Org. Chem. 1972, 37, 2901. (d) Basset, J. F.; Leslie, C.; Hamprecht, D.; White, A. J. P.; Barrett, A. G. M. Tetrahedron Lett. 2010, 51, 783. (e) Chan, T. H.; Chaly, T. Tetrahedron Lett. 1982, 23, 2935. (f) Crombie, L.; Crombie, M. L. Phytochemistry 1977, 16, 1413. (g) Girard, M.; Moir, D. B.; Simon, J. A. Can. J. Chem. 1987, 65, 189. (h) Trost, B. M.; Dogra, K. Org. Lett. 2007, 9, 861.

(6) Liu, X.; Chen, J.; Ma, T. Org. Biomol. Chem. 2018, 16, 8662.

(7) Zhang, J.; Jiang, Q.; Yang, D.; Zhao, X.; Dong, Y.; Liu, R. Chem. Sci. 2015, 6, 4674.

(8) Liang, Y. F.; Song, S.; Ai, L.; Li, X.; Jiao, N. Green Chem. 2016, 18 , 6462.

(9) (a) Kotnis, A. S. Tetrahedron Lett. 1991, 32, 3441. (b) Geng, Z.-Z.; Zhang, J.-J.; Lin, J.; Huang, M.-Y.; An, L.-K.; Zhang, H.-B.; Sun, P.H.; Ye, W.-C.; Chen, W.-M. Eur. J. Med. Chem. 2015, 100, 235.
(10) Synthesis of Diketo Ester 8: To a solution of dimethyl malonate $(12 \mathrm{~mL}, 100 \mathrm{mmol})$ in methanol $(20 \mathrm{~mL})$ was added a $25 \mathrm{wt} \%$ solution of sodium methoxide in methanol $(20 \mathrm{~mL}, 89 \mathrm{mmol})$. To the resulting solution was added $(E)-3$-nonen-2-one $(12 \mathrm{~mL}$, $70 \mathrm{mmol}$ ) over $0.5 \mathrm{~h}$ with vigorous stirring. The pale-yellow slurry was heated at reflux over $3 \mathrm{~h}$ under a nitrogen atmosphere. Upon cooling, the resulting yellow solution was cooled to room temperature then methanol was removed using a rotary evaporator with heating not exceeding $40^{\circ} \mathrm{C}$. To the paleyellow solid was added water $(70 \mathrm{~mL})$ and diethyl ether $(10 \mathrm{~mL})$ and the mixture was stirred until no visible solid remained. The biphasic mixture was extracted with diethyl ether $(2 \times 50 \mathrm{~mL})$. The clear orange aqueous solution was carefully adjusted to $\mathrm{pH}$ 4 with $\mathrm{HCl}$ conc. and allowed to stand at room temperature for 12 h. The desired product 8 was obtained as a mixture of isomers by vacuum filtration as a white crystalline solid ( 12.54 g, 74\%). ${ }^{1} \mathrm{H}$ NMR $\left(600 \mathrm{MHz}, \mathrm{CDCl}_{3}\right): \delta=5.48(\mathrm{~s}, 1 \mathrm{H}), 3.82(\mathrm{~s}, 3 \mathrm{H})$, $3.80(\mathrm{~s}, 3 \mathrm{H}), 3.76(\mathrm{~s}, 3 \mathrm{H}), 3.68(\mathrm{dd}, J=17.2,0.8 \mathrm{~Hz}, 1 \mathrm{H}), 3.45(\mathrm{~d}$, $J=6.7 \mathrm{~Hz}, 1 \mathrm{H}), 3.39(\mathrm{~d}, J=17.2 \mathrm{~Hz}, 1 \mathrm{H}), 3.17(\mathrm{~d}, J=10.0 \mathrm{~Hz}, 1$ $\mathrm{H}), 2.84(\mathrm{dd}, J=15.4,4.5 \mathrm{~Hz}, 1 \mathrm{H}), 2.61$ (dd, $J=17.5,4.8 \mathrm{~Hz}, 1 \mathrm{H})$, 2.54-2.46 (m, $1 \mathrm{H}), 2.43(\mathrm{dd}, J=15.4,7.5 \mathrm{~Hz}, 1 \mathrm{H}), 2.19(\mathrm{dd}, J=$ 17.5, $9.9 \mathrm{~Hz}, 1 \mathrm{H}), 1.46-1.17$ (m, $8 \mathrm{H}), 0.87$ (m, $3 \mathrm{H}) .{ }^{13} \mathrm{C}$ NMR $\left(151 \mathrm{MHz}, \mathrm{CDCl}_{3}\right): \delta=206.69,202.36,198.93,191.19,185.55$, 171.94, 171.32, 169.34, 167.94, 103.98, 102.84, 60.78, 57.53, 56.86, 52.78, 52.38, 51.80, 44.03, 43.12, 42.62, 36.24, 35.71, $34.73,33.77,33.48,33.41,31.75,31.62,31.57,31.34,26.57$, $25.95,25.85,22.47,22.38,13.96,13.91$.

(11) Synthesis of Cyclic Diketone 9: To a solution of dimethyl malonate $(11.5 \mathrm{~mL}, 100.4 \mathrm{mmol})$ in methanol $(20 \mathrm{~mL})$ was added a $25 \mathrm{wt} \%$ solution of sodium methoxide in methanol (20 $\mathrm{mL}, 89 \mathrm{mmol})$. To the resulting slurry was added $(E)-3-$ nonen2-one (11.6 mL, $70.2 \mathrm{mmol}$ ) over $0.5 \mathrm{~h}$ with vigorous stirring. The pale-yellow slurry was heated at reflux over $3 \mathrm{~h}$ under a nitrogen atmosphere. The resulting yellow solution was cooled to room temperature whereupon the methanol was removed using a rotary evaporator with heating not exceeding $40^{\circ} \mathrm{C}$. The resulting yellow solid was dissolved in $20 \mathrm{wt} \%$ sodium hydroxide solution $(70 \mathrm{~mL})$ then heated at reflux over $2.5 \mathrm{~h}$. The solution was cooled to room temperature, then extracted with diethyl ether $(2 \times 50 \mathrm{~mL})$. To the aqueous solution was added $\mathrm{HCl}$ until rapid gas evolution was observed $(30 \mathrm{~mL})$, the effervescent, clear yellow solution was heated at reflux over $1 \mathrm{~h}$, then the aqueous solution was slowly acidified with $\mathrm{HCl}$ conc. to the first appearance of a precipitate (pH 5) and left to stand over 12 h. The desired product $\mathbf{9}$ was obtained by vacuum filtration, then drying under high vacuum (ca. $0.1 \mathrm{mmHg}$ ) to afford a palepink solid as a mixture of tautomers (10.88 g, $84 \%)$. ${ }^{1} \mathrm{H}$ NMR $\left(600 \mathrm{MHz}, \mathrm{CDCl}_{3}\right): \delta=5.49(\mathrm{~s}, 1 \mathrm{H}), 3.66(\mathrm{~s}, 1 \mathrm{H}), 3.37(\mathrm{~s}, 2 \mathrm{H})$, $2.73(\mathrm{dd}, J=15.5,3.8 \mathrm{~Hz}, 1 \mathrm{H}), 2.45(\mathrm{~d}, J=12.5 \mathrm{~Hz}, 1 \mathrm{H}), 2.36$ (dd, $J=15.4,10.3 \mathrm{~Hz}, 1 \mathrm{H}), 2.20-1.98(\mathrm{~m}, 2 \mathrm{H}), 1.45-1.19(\mathrm{~m}, 8 \mathrm{H})$, $0.88(\mathrm{t}, J=6.9 \mathrm{~Hz}, 3 \mathrm{H}) .{ }^{13} \mathrm{C} \mathrm{NMR}\left(151 \mathrm{MHz}, \mathrm{CDCl}_{3}\right): \delta=203.84$, 191.74, 104.24, 57.99, 46.39, 38.82, 35.44, 35.21, 33.75, 31.76, 31.57, 30.66, 26.26, 26.21, 22.56, 22.48, 14.01, 13.96.

(12) Synthesis of Olivetolic Acid Methyl Ester 3: To a solution of 8 $(6.9391 \mathrm{~g}, 28.87 \mathrm{mmol})$ in DMSO $(7 \mathrm{~mL})$ was added iodine ( $1.0236 \mathrm{~g}, 4.03 \mathrm{mmol}$ ) and the brown solution was stirred at 80 ${ }^{\circ} \mathrm{C}$ for $24 \mathrm{~h}$. The reaction mixture was diluted with ethyl acetate $(70 \mathrm{~mL})$, then extracted with $0.1 \mathrm{M}$ sodium thiosulfate $(3 \times 10$ $\mathrm{mL})$, then water $(10 \mathrm{~mL})$. The organic solution was concentrated in vacuo to afford a viscous dark-red liquid. The crude material was passed through a plug of silica, using hexanes-ethyl acetate $(4: 1)$ to elute. The eluent was concentrated and dried under reduced pressure (ca. $0.1 \mathrm{mmHg}$ ) to afford the desired product 3 
as a pale-yellow crystalline solid $(6.050 \mathrm{~g}, 88 \%) .{ }^{1} \mathrm{H}$ NMR (600 $\left.\mathrm{MHz}, \mathrm{CDCl}_{3}\right): \delta=11.78(\mathrm{~s}, 1 \mathrm{H}), 6.29(\mathrm{~d}, J=2.5 \mathrm{~Hz}, 1 \mathrm{H}), 6.24(\mathrm{~d}$, $J=2.5 \mathrm{~Hz}, 1 \mathrm{H}), 3.92(\mathrm{~s}, 3 \mathrm{H}), 2.81(\mathrm{dd}, J=8.9,6.8 \mathrm{~Hz}, 2 \mathrm{H}), 1.58-$ $1.47(\mathrm{~m}, 2 \mathrm{H}), 1.39-1.28(\mathrm{~m}, 4 \mathrm{H}), 0.90(\mathrm{t}, J=6.8 \mathrm{~Hz}, 3 \mathrm{H}) .{ }^{13} \mathrm{C}$ NMR $\left(151 \mathrm{MHz}, \mathrm{CDCl}_{3}\right): \delta=172.03,165.08,160.59,149.00$, $110.96,104.91,101.39,51.95,36.81,32.07,31.47,22.51,14.07$.

(13) Synthesis of Olivetol 1: To solution of $9(10.88 \mathrm{~g}, 59.7 \mathrm{mmol})$ in DMSO $(10 \mathrm{~mL})$ was added iodine $(0.4837 \mathrm{~g}, 1.9 \mathrm{mmol})$ and the brown solution was stirred in an $80^{\circ} \mathrm{C}$ bath over $27 \mathrm{~h}$. The reaction mixture was diluted with ethyl acetate $(100 \mathrm{~mL})$ then extracted with $0.1 \mathrm{M}$ sodium thiosulfate $(50 \mathrm{~mL})$. The aqueous phase was extracted with ethyl acetate $(3 \times 50 \mathrm{~mL})$, and the organic fractions were pooled, and concentrated in vacuo to afford a viscous dark-red liquid. The crude material was distilled under reduced pressure (ca. $0.1 \mathrm{mmHg}, 80^{\circ} \mathrm{C}$ ) to afford olivetol 1 as a colourless crystalline solid (5.051 g, 48\%). ${ }^{1} \mathrm{H}$ NMR $\left(600 \mathrm{MHz}, \mathrm{CDCl}_{3}\right): \delta=6.26(\mathrm{~d}, J=2.1 \mathrm{~Hz}, 2 \mathrm{H}), 6.18(\mathrm{t}, J=2.2 \mathrm{~Hz}$, $1 \mathrm{H}), 5.01$ (s, $2 \mathrm{H}), 2.51-2.44(\mathrm{~m}, 2 \mathrm{H}), 1.61-1.53$ (m, $2 \mathrm{H}), 1.40-$ $1.21(\mathrm{~m}, 4 \mathrm{H}), 0.88(\mathrm{t}, J=7.0 \mathrm{~Hz}, 3 \mathrm{H}) .{ }^{13} \mathrm{C}$ NMR $(151 \mathrm{MHz}$, $\left.\mathrm{CDCl}_{3}\right): \delta=156.46,146.26,108.16,100.20,35.79,31.46,30.72$, $22.53,14.02$.

(14) Synthesis of Methyl Olivetolate Monomethyl Ether 4: To a round-bottom flask charged with methanol $(4 \mathrm{~mL})$ was added 8 (480.6 mg, $2.00 \mathrm{mmol}$ ), iodine (100.0 $\mathrm{mg}, 0.394 \mathrm{mmol}$ ) and DMSO (234.0 mg, $3.00 \mathrm{mmol}$ ) and the mixture was heated at reflux over $72 \mathrm{~h}$ until the disappearance of $\mathbf{8}$ was observed. The reaction mixture was quenched with dropwise addition of $\mathrm{Na}_{2} \mathrm{~S}_{2} \mathrm{O}_{3}(0.1 \mathrm{M}, 10 \mathrm{~mL})$, then extracted with hexanes $(3 \times 5 \mathrm{~mL})$. The combined organic fractions were washed with water $(5$ $\mathrm{mL}$ ), dried over $\mathrm{Na}_{2} \mathrm{SO}_{4}$, filtered, and concentrated to give a pale- yellow oil. The crude mixture was purified by flash chromatography using hexane-ethyl acetate (4:1) as eluent to give $\mathbf{4}$ as a colourless oil (138.2 mg, 27\%). ${ }^{1} \mathrm{H}$ NMR $\left(600 \mathrm{MHz}, \mathrm{CDCl}_{3}\right): \delta=$ $11.73(\mathrm{~s}, 1 \mathrm{H}), 6.32(\mathrm{~d}, J=2.6 \mathrm{~Hz}, 1 \mathrm{H}), 6.28(\mathrm{~d}, J=2.6 \mathrm{~Hz}, 1 \mathrm{H})$, $3.91(\mathrm{~s}, 3 \mathrm{H}), 3.78(\mathrm{~s}, 3 \mathrm{H}), 2.85-2.81(\mathrm{~m}, 2 \mathrm{H}), 1.56-1.48(\mathrm{~m}, 2$ $\mathrm{H}), 1.35-1.31(\mathrm{~m}, 4 \mathrm{H}), 0.90(\mathrm{t}, J=6.9 \mathrm{~Hz}, 3 \mathrm{H}) .{ }^{13} \mathrm{C}$ NMR $(151$ $\left.\mathrm{MHz}, \mathrm{CDCl}_{3}\right): \delta=171.98,165.59,163.97,148.04,110.60,104.59$, $98.75,55.20,51.78,36.89,32.08,31.55,22.52,14.06$.

(15) Synthesis of Methyl Olivetolate Monomethyl Ether 4 and Methyl Olivetolate Dimethyl Ether 5: To a round-bottom flask charged with methanol $(4 \mathrm{~mL})$ was added $8(481.0 \mathrm{mg}, 2.00$ $\mathrm{mmol})$, iodine $(101.2 \mathrm{mg}, 0.399 \mathrm{mmol})$ and trimethyl orthoformate $(0.8 \mathrm{~mL}, 8.0 \mathrm{mmol})$. The solution was stirred under nitrogen, at room temperature, over $1 \mathrm{~h}$, until consumption of $\mathbf{8}$ was observed. DMSO (234.1 $\mathrm{mg}, 3.00 \mathrm{mmol}$ ) was added and the mixture was heated at reflux over $72 \mathrm{~h}$. The reaction mixture was quenched by dropwise addition of $\mathrm{Na}_{2} \mathrm{~S}_{2} \mathrm{O}_{3}(0.1 \mathrm{M}, 10 \mathrm{~mL})$, then extracted with hexanes $(3 \times 5 \mathrm{~mL})$. The combined organic fractions were washed with water $(5 \mathrm{~mL})$, dried over $\mathrm{Na}_{2} \mathrm{SO}_{4}$, filtered and concentrated to give a pale-yellow oil. The crude mixture was purified by flash chromatography using hexaneethyl acetate (4:1) as eluent to give $\mathbf{4}$ as a colourless oil (108.3 $\mathrm{mg}, 21 \%)$ and 5 as a colourless oil (210.9 mg, 49\%). ${ }^{1} \mathrm{H}$ NMR (600 $\left.\mathrm{MHz}, \mathrm{CDCl}_{3}\right): \delta=6.33(\mathrm{~d}, J=2.1 \mathrm{~Hz}, 1 \mathrm{H}), 6.31(\mathrm{~d}, J=2.2 \mathrm{~Hz}, 1 \mathrm{H})$, 3.88 (s, $1 \mathrm{H}), 3.81$ (s, $1 \mathrm{H}), 3.79(\mathrm{~s}, 1 \mathrm{H}), 2.56-2.51(\mathrm{~m}, 1 \mathrm{H}), 1.61-$ $1.54(\mathrm{~m}, 1 \mathrm{H}), 1.33-1.29(\mathrm{~m}, 1 \mathrm{H}), 0.88(\mathrm{t}, J=7.0 \mathrm{~Hz}, 1 \mathrm{H}) .{ }^{13} \mathrm{C}$ NMR $\left(151 \mathrm{MHz}, \mathrm{CDCl}_{3}\right): \delta=168.98,161.40,157.99,143.10$, 116.20, 105.83, 96.09, 55.84, 55.31, 52.03, 33.90, 31.68, 30.86, $22.43,13.96$. 